\title{
High species richness in deep-sea chemoautotrophic whale skeleton communities
}

\author{
Amy R. Baco ${ }^{1,2, *}$, Craig R. Smith ${ }^{1}$ \\ ${ }^{1}$ Department of Oceanography, 1000 Pope Road, Honolulu, Hawaii 96822, USA \\ ${ }^{2}$ Present address: Woods Hole Oceanographic Institution, Biology Department, MS\#33 2-14 Redfield, Woods Hole, \\ Massachusetts 02543, USA
}

\begin{abstract}
While biodiversity in deep-sea soft sediments appears to be high, little is known about diversity levels on deep-sea hard substrates. To determine the contribution of potentially abundant whale-skeleton habitats to deep-sea biodiversity, we compare the local macrofaunal species richness and composition on 3 sulfide-rich whale skeletons to assemblages from vents, seeps, and other deepsea hard substrates. Based on rarefaction curves, whale skeleton diversity is higher than diversity in any other deep-sea hard substrate habitat. The average local species richness (185 spp.) on single chemoautotrophic whale skeletons approaches known levels of global cold-seep macrofaunal species richness (229 spp.), and exceeds the richness of the most speciose vent field known (121 spp.). Species richness on the whale skeletons is also substantially higher than on other deep-sea nonreducing hard substrates, such as manganese nodules and rocks. Richness levels approach those in deep-sea soft sediments and exceed some shallow-water hard substrates. This high species richness may be explained by unusually high trophic diversity on whale bones due to the presence of sulphophiles, generalized organic-enrichment respondents, whale-bone consumers, and background hard-substrate fauna such as suspension and deposit feeders. High species richness levels on whale skeletons and deep-sea sponge stalks suggest deep-sea hard substrates may harbor higher levels of diversity than previously recognized.
\end{abstract}

KEY WORDS: Whale fall $\cdot$ Species richness $\cdot$ Biodiversity $\cdot$ Deep sea $\cdot$ Hard substrate

\section{INTRODUCTION}

Documentation of biodiversity patterns in the deep sea is fundamental to understanding the ecological and evolutionary novelties of the ocean. A number of studies suggest that deep-sea soft-sediments often contain high levels of local diversity, and global biodiversity in deepsea sediments may be similarly high (reviewed in Snelgrove \& Smith 2002). While substantially more data are required to critically evaluate the biodiversity of the sedimentary deep sea, even less is known of biodiversity patterns on deep-sea hard substrates. Hard substrates occur in a range of divergent deep-ocean habitats, including rock outcrops, manganese nodules, hydrothermal vents, cold seeps, sponge stalks and whale skeletons. Because these habitats vary dramatically in geographical distribution, dynamics, and chemical conditions, each is likely to harbor characteristic macrofaunal communities with distinct patterns of biodiversity.

Here we begin evaluation of biodiversity patterns in one type of potentially abundant hard-substrate community in the deep sea: sulfide-rich whale skeletons. Smith \& Baco (2003) estimate that, at any given time, there may be $>500000$ sulfide-rich whale skeletons at the deep-sea floor. Prior to the advent of industrial whaling in approximately 1800, the number of sulfiderich whale skeletons may have been 2- to 5-fold higher (Butman et al. 1995, Smith \& Baco 2003).

Whale falls may promote high biodiversity in the deep sea by providing hard substrates, organic enrichment, and free sulfides at a typically sediment-covered, organic-poor deep-sea floor (Bennett et al. 1994, But- 


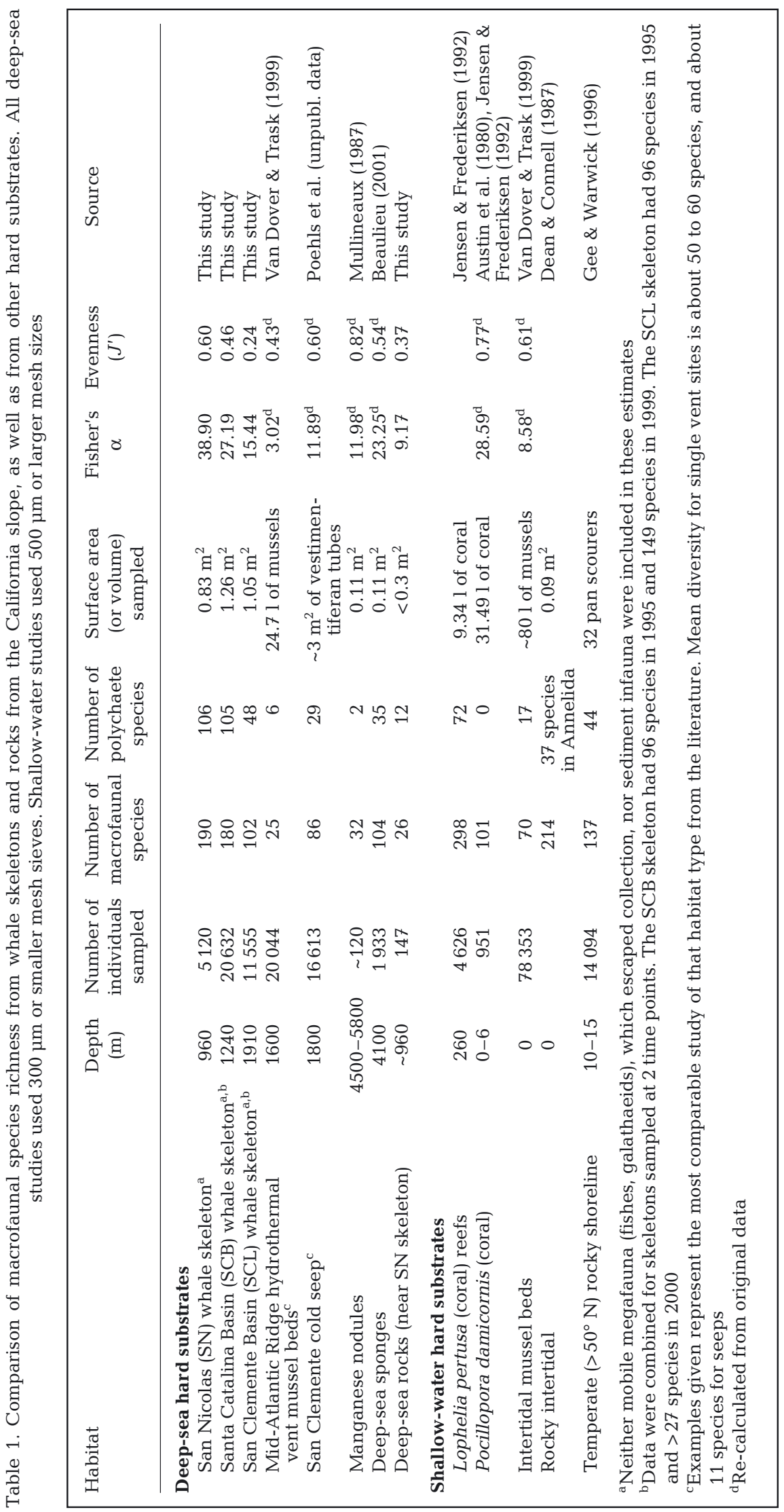

man et al. 1995, Smith \& Baco 2003). However, only 2 studies have quantitatively addressed whale-fall community composition, and these studies were conducted at a single site (Bennett et al. 1994, Smith et al. 1998). Here we evaluate macrofaunal species richness on 3 sulfiderich whale skeletons separated by hundreds of kilometers off southern California, and we discover them to be remarkably diverse.

\section{MATERIALS AND METHODS}

Study sites and sampling. To determine macrofaunal species richness levels on lipid-rich whale falls, we collected 1 to 7 vertebral bones from each of 3 skeletons on the California slope between 1995 and 2000 (San Nicolas, 960 m, 33²0' N, $119^{\circ} 59^{\prime} \mathrm{W}_{\text {; }}$ Santa Catalina Basin, $1240 \mathrm{~m}, 33^{\circ} 12^{\prime} \mathrm{N}, 118^{\circ} 29^{\prime} \mathrm{W}$; San Clemente Basin, $1910 \mathrm{~m}, 32^{\circ} 26^{\prime} \mathrm{N}$, $118^{\circ} 9^{\prime} \mathrm{W}$ ) as well as rocks at 2 locations in the general vicinity at similar depths $\left(960 \mathrm{~m}, 33^{\circ} 15^{\prime} \mathrm{N}, 119^{\circ} 56^{\prime} \mathrm{W}\right.$ and $\left.33^{\circ} 15^{\prime} \mathrm{N}, 119^{\circ} 20^{\prime} \mathrm{W}\right)$. Bones were collected using a submersible or remotely operated vehicle (ROV) manipulator and placed in sealed boxes. (Some fauna may have fallen from bones during initial collection with the manipulator arm, so diversity and abundance estimates represent a slight underestimate for these samples.) The boxes were brought to the surface and epifauna that fell from the bones into the box during transport was collected by washing box residues on a $300 \mu \mathrm{m}$ sieve. All visible epifauna was removed from the surfaces of the bones upon recovery. All samples were immediately fixed in $10 \%$ formaldehyde/ seawater solution and later transferred to $80 \%$ ethanol. Samples were stained with Rose Bengal, and macrofauna were sorted to species using a dissecting microscope. Bone surface areas were estimated by weighing the amount of aluminum foil required to fully cover bone sur- 
faces in a monolayer. The sampled surface area of the bones above the sediment-water interface for each skeleton, as well as the total numbers of macrofaunal individuals and species, are given in Table 1. Sediment fauna, bone meiofauna, and mobile megafauna are not included in these estimates.

For the 2 skeletons sampled at more than 1 time point, Santa Catalina Basin and San Clemente Basin, species lists were combined for data analyses. For each of these skeletons, the communities at the times sampled appeared to be in the same successional stage (dominant species, etc.) and changes in diversity were related to sampling intensity.

Data analyses. The available data on quantitative studies of hard substrate macrofauna that are listed in Table 1 come from a variety of studies. All of the deepsea hard substrate studies included for comparison used a sieve mesh size of $300 \mu \mathrm{m}$ or smaller. Shallow-water studies used a mesh size of $500 \mu \mathrm{m}$ or larger. Each study has a different number of sample units and a different total sample area, so the diversity indices we used for comparison to the whale falls had to be independent of sample size. To compare macrofaunal sample species richness (i.e. the total species richness of the sampling units from a given site, following the nomenclature of Gray 2000) on whale falls with the macrofaunal sample species richness on other hard-substrate habitats, we calculated rarefaction curves (Hurlbert 1971), and Fisher's alpha $(\alpha)$ (Hayek \& Buzas 1997). Rarefaction is an estimate of the number of species that would be found in a given number of individuals, extrapolated from the total number of species and individuals collected. This method allows larger sample sizes to be compared to smaller ones (Hayek \& Buzas 1997, Gray 2000). Fisher's $\alpha$ is a diversity index that is an estimate of the number of species in a sample expected to be represented by 1 individual (Hayek \& Buzas 1997). Shannon-Wiener $\left(H^{\prime}\right)$ is a more commonly used index for diversity comparisons, however, $H^{\prime}$ has been shown to be less informative than other diversity indices (e.g. Magurran 1988, Gray 2000). Fisher's $\alpha$ and Hurlbert rarefaction curves are less sensitive to differences in sample size than $H^{\prime}$, and $\alpha$ is less sensitive to evenness than $H^{\prime}$ (Hayek \& Buzas 1997). Therefore, we considered rarefaction and $\alpha$ to be more appropriate for our species richness comparisons. Evenness values $\left(J^{\prime}\right)$ are also included to provide information on species abundance structure. Rarefaction, $\alpha$, and $J^{\prime}$ were calculated using BioDiversity Pro software (McAleece et al. 1997) and are included in Table 1.

\section{RESULTS AND DISCUSSION}

The San Nicolas (SN) whale skeleton exhibited the greatest species richness, with a total of 190 macro- faunal species in 10 phyla collected in 5120 individuals (Table 1). The Santa Catalina Basin (SCB) skeleton also had very high species richness with 180 species. The San Clemente Basin (SCL) skeleton had lower species richness, with 102 species. Stable isotope studies indicate that the SCL skeleton fauna are not dependent on chemoautotrophic production (Baco-Taylor 2002, Baco \& Smith unpubl. data). The range of niches associated with chemoautotrophic production may be absent at this site, resulting in substantially lower levels of species richness.

The most speciose taxon on all 3 whale skeletons was the polychaetes, with particular diversity in the families Dorvilleidae, Ampharetidae, and Polynoidae. Molluscs were numerically dominant at all 3 sites with the chemoautotrophic-endosymbiont hosting mytilid bivalve Idas washingtonia the most abundant (BacoTaylor 2002, Baco \& Smith unpubl. data).

We compared macrofaunal diversity on the whale bones to existing data for deep-sea soft sediments (Jumars 1974) using Hurlbert rarefaction curves (Hurlbert 1971), and the results are shown in Fig. 1. The height of a rarefaction curve is a function of community species richness, and curve steepness is a function of species evenness. The SN skeleton had slightly higher richness and evenness than SCB sediments, but lower than San Diego Trough sediments. Richness and evenness were lower for the SCB skeleton and the SCL skeleton than in background SCB sediments. The low species overlap between the SCB skeleton and background SCB sediments $(<3 \%)$ indicates that the communities found on whale skeletons are discrete assemblages, rather than subsets of sediment communities (Bennett et al. 1994).

Based on species number, $\alpha$ (Table 1), and rarefaction (Fig. 2), macrofaunal species richness was sub-

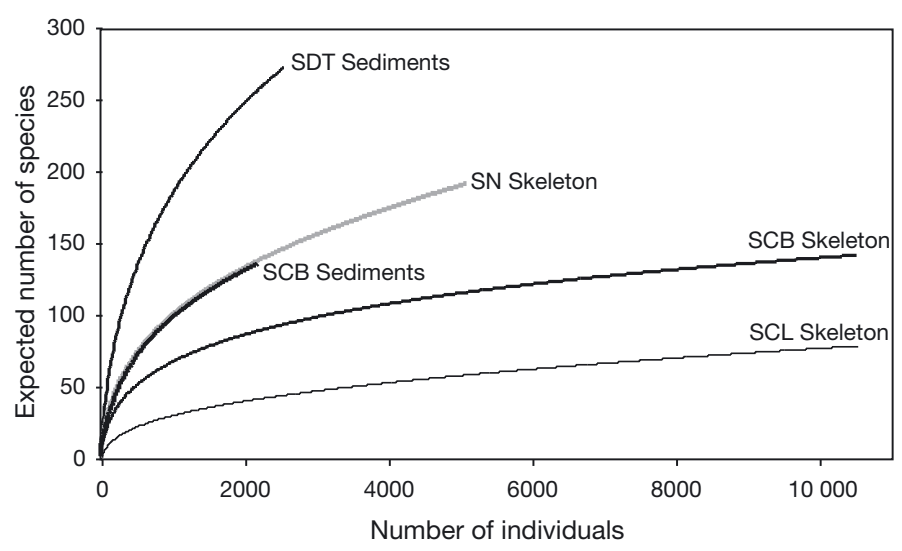

Fig. 1. Hurlbert rarefaction curves for all macrofauna are given for San Diego Trough (SDT) and Santa Catalina Basin (SCB) sediments, and from each whale skeleton from this study. SN: San Nicolas; SCL: San Clemente Basin 


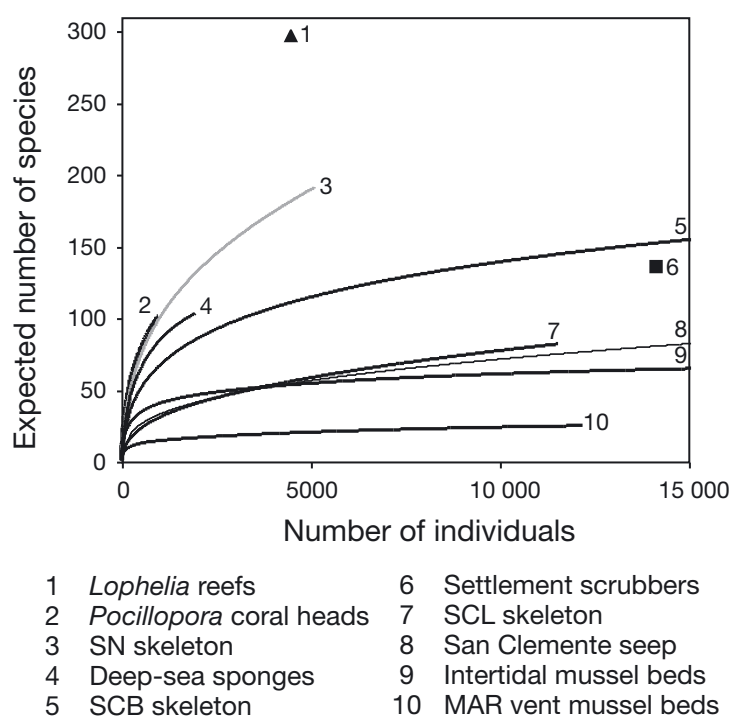

Fig. 2. Hurlbert rarefaction curves for hard-substrate habitats. Shallow-water corals had the highest diversity of all hardsubstrate habitats based on rarefaction, but lower $\alpha$ values than the SN skeleton. Therefore, while chemoautotrophic whale skeletons are the most species-rich deep-sea hardsubstrate habitats, their overall species richness is intermediate compared to shallow-water hard-substrate habitats. MAR: Mid-Atlantic Ridge

stantially higher at the SN whale skeleton than on any other deep-sea hard substrate thus far studied. The SCB skeleton also had high diversity based on species number and $\alpha$. Deep-sea sponges had rarefaction curves that were higher than the SCB skeleton; however this may be a function of higher evenness (sponge $J^{\prime}=0.54$ vs SCB $J^{\prime}=0.46$ ) rather than higher species richness. The SCL skeleton had higher diversity than hydrothermal vents and cold seeps based on rarefaction, and higher diversity than rocks, seeps, vents, and manganese nodules based on $\alpha$. Polychaete species richness was also higher on whale skeletons than on any other hard substrate (Table 1). Overall species evenness was highest on manganese nodules and at the San Clemente cold seep (Table 1).
We also compared species richness on whale falls to shallow-water hard substrates. Rarefaction curves (Fig. 2) and $\alpha$ for intertidal mussel beds in Alaska (Van Dover \& Trask 1999) showed lower species richness than any of the whale skeletons. A comparable data set for rocky shorelines was not available, but a preliminary study of 'settlement scrubbers' implanted on rocky shorelines (Gee \& Warwick 1996) had an overall species richness intermediate between the SCB and SCL skeletons. A study of invertebrate succession in the rocky intertidal (Dean \& Connell 1987) found higher overall species number than on any of the whale skeletons. Shallow-water corals had the highest diversity of all hard-substrate habitats based on rarefaction, but lower $\alpha$-values than the SN skeleton. Therefore, while chemoautotrophic whale skeletons had the highest local species richness of any known deep-sea hard-substrate habitats, their overall species richness may be intermediate compared to shallowwater hard-substrate habitats.

Despite being one of the least-studied deep-sea reducing habitats, whale falls may harbor the highest levels of global species richness. Table 2 provides a comparison of the current estimates for species richness for worldwide whale-fall, vent and seep habitats. However, the value for worldwide whale-fall habitats is clearly a substantial underestimate because $91 \%$ of the estimate is based on the skeleton epifauna from the California Slope. The remaining 9\% of the species were collected from partial skeletons recovered in various ocean basins and from bones implanted on the Hawaiian Slope (Dell 1987, 1995, Gibbs 1987, Marshall 1987, 1994, Waren 1989, 1991, 1993, Bennett et al. 1994, Baco-Taylor 2002, Baco \& Smith unpubl. data). Not surprisingly, only one of the species collected at these distant sites was shared with the southern California whale skeletons, suggesting that comprehensive sampling of additional skeletons will lead to substantially higher global diversity estimates. Global diversity of whale-fall habitats will also increase substantially when the sedimentary communities associated with the whale falls are analyzed for species richness.

Table 2. Comparison of global diversity among deep-sea reducing habitats

\begin{tabular}{|c|c|c|c|c|}
\hline Habitat & $\begin{array}{c}\text { Substrate } \\
\text { type }\end{array}$ & $\begin{array}{l}\text { Number of } \\
\text { macrofaunal } \\
\text { species }\end{array}$ & $\begin{array}{c}\text { Number of } \\
\text { polychaete } \\
\text { species }\end{array}$ & Source \\
\hline Whale skeletons & $\operatorname{Hard}^{\mathrm{a}}$ & $\gg 407$ & $201+$ & $\begin{array}{l}\text { This study, Dell (1987), Gibbs (1987), Marshall (1987), Waren } \\
\text { (1989, 1991, 1993, 1996), Bennett et al. (1994), Marshall (1994), } \\
\text { Dell (1995), Baco-Taylor (2002), Baco \& Smith (unpubl. data) }\end{array}$ \\
\hline Hydrothermal vents & Hard/soft & 469 & 100 & Tunnicliffe et al. (1998), Hashimoto et al. (2001) \\
\hline Cold seeps & Soft/hard & 229 & 25 & Sibuet \& Olu (1998), Poehls et al. (unpubl. data) \\
\hline
\end{tabular}


Whale skeletons in the chemoautotrophic stage appear to harbor the highest local sample species richness of any hard substrate in the deep sea. We hypothesize that this high richness results from the broad array of ecological niches found on whale skeletons. Four main trophic types may be present: (1) Sulphophiles: Animals attracted to concentrations of free sulfides found on whale skeletons that directly or indirectly exploit sulfur-based microbial chemoautotrophic production. Sulphophilic species may arrive from other reducing habitats or may be whale-fall specialists and include bacterial mat grazers and species with chemoautotrophic endosymbionts. Nineteen of the species collected on whale falls have been documented from other reducing habitats, including deep-sea hydrothermal vents and cold seeps (Smith \& Baco 1998, 2003, Baco et al. 1999, Baco-Taylor 2002, Baco \& Smith unpubl. data, Poehls et al. unpubl. data). In fact, whale skeletons may act as dispersal and evolutionary stepping-stones for species dependent on chemoautotrophy (Smith et al. 1989, Baco et al. 1999, unpubl. data, Distel et al. 2000, Baco-Taylor 2002, Smith \& Baco 2003). (2) Bone-matrix feeders: Animals that exploit the lipid/protein organic matrix of the bones as part of their life cycle. An example is the whale-endemic sipunculid Phascolosoma saprophagicum, which feeds directly on bone lipids (Gibbs 1987). (3) Generalized organic enrichment respondents: Species such as dorvilleid polychaetes that respond to intense organic loading (Pearson \& Rosenberg 1978, Smith \& Baco 2003). These species may feed directly on detrital organic material or may feed on heterotrophic bacteria decomposing the whale organics. (4) Background species: Because the sulphide concentrations on all portions of whale skeletons do not reach the levels found at other reducing habitats, background hard-substrate species such as deposit- or suspension-feeding ampharetid polychaetes, anemones, and sponges, may be able to colonize. These species may also take advantage of enhanced microbial production or current intensification around the bones.

Species richness on whale skeletons may be enhanced by the presence of whale-fall specialists. Large whales first appeared in the fossil record approximately 40 Myr ago (Briggs \& Crowther 1990), providing sufficient evolutionary time for an endemic fauna to develop. Twenty species have been found on whale skeletons only (Dell 1987, 1995, Gibbs 1987, Marshall 1987, 1994, Waren 1989, 1991, 1993, 1996, McLean 1992, Pettibone 1993, Bennett et al. 1994, Williams et al. 2000). Additional specialists, mainly Idas washingtonia, Cocculina craigsmithi, Pyropelta corymba and Pyropelta musaica, have population sizes of 1000 to 20000 individuals on whale skeletons, with only a few individuals rarely occurring in other types of habitat (Bennett et al. 1994, Baco-Taylor 2002, Smith \& Baco 2003, Baco \& Smith unpubl. data, ). Whale-bone specialists and endemics may include species directly consuming bone organic material (e.g. Gibbs 1987, Marshall 1994) or species that appear to facultatively utilize chemoautotrophic production, such as I. washingtonia (BacoTaylor 2002, Baco \& Smith unpubl. data).

Whale skeletons appear to support productive communities for decades (Smith et al. 1989, Schuller et al. in press, Baco \& Smith unpubl. data). This persistence, along with a complex suite of niches, combines to produce a unique habitat where sulphophiles from other reducing habitat types, background species, opportunistic organic enrichment respondents, and whalefall specialists overlap to produce high species richness.

A further examination of Fig. 2 and Table 1 suggests that hard-substrate habitats fall into 3 diversity categories: (1) those with high species richness, which include the SN and SCB skeletons, deep-sea sponges, and coral reefs; (2) those with intermediate species richness, which include manganese nodules, the non-chemoautotrophic whale skeleton (SCL), seeps, and temperate intertidal mussel beds; (3) those with low diversity, including mid-Atlantic Ridge hydrothermal vents.

The high species richness on whale skeletons and deep-sea sponges is particularly noteworthy. These are among the first deep-sea hard substrates for which macrofaunal species richness has been quantitatively measured, and there is little species overlap between them (Beaulieu 2001, Baco \& Smith unpubl. data).

On a global scale, other deep-sea hard-substrate habitats are also likely to be undersampled. Hydrothermal vents and cold seeps are perhaps the best-studied deep-sea habitats, but quantitative hard-substrate sampling has been attempted only recently (Van Dover \& Trask 1999, Fisher unpubl. data, Poehls et al. unpubl. data), and major portions of the mid-ocean ridge system (along with many cold seeps) remain unsampled (Van Dover et al. 2002). Reviews of global macrofaunal species richness have also not been made for any nonreducing hard-substrate habitats in the deep sea. We suggest that deep-sea hard substrates may harbor substantial, yet very poorly evaluated, levels of biodiversity on both local and global scales.

Acknowledgements. This research was generously supported by grants to C.R.S. from NOAA's National Undersea Research Program, Alaska UAF-95-0040 and UAF-97-0038; and from the National Geographic Society and the BBC. A.R.B. received partial salary support from an EPA STAR Graduate Fellowship. We thank the captains and crews of the RVs 'Atlantis', 'Atlantis II', and 'Laney Chouest', the pilots and staff of the 'Alvin' and 'Turtle' submersibles and the ROV ATV. This is contribution no. 6211 from the School of Ocean and Earth Science and Technology, University of Hawaii at Manoa. 


\section{LITERATURE CITED}

Austin AD, Austin SA, Sale PF (1980) Community structure of the fauna associated with the coral Pocillopora damicornis (1.) on the Great Barrier Reef. Aust J Mar Freshw Res 31: $35-47$

Baco AR, Smith CR, Peek AS, Roderick GK, Vrijenhoek RC (1999) The phylogenetic relationships of whale-fall vesicomyid clams based on mitochondrial COI DNA sequences. Mar Ecol Prog Ser 182:137-147

Baco-Taylor AR (2002) Food-web structure, succession, and phylogenetic affinities on deep-sea whale skeletons. PhD dissertation, Department of Oceanography, Honolulu, HI

Beaulieu SE (2001) Life on glass houses: sponge stalk communities in the deep sea. Mar Biol 138:803-817

Bennett BA, Smith CR, Glaser B, Maybaum HL (1994) Faunal community structure of a chemoautotrophic assemblage on whale bones in the deep northeast Pacific Ocean. Mar Ecol Prog Ser 108:205-223

Briggs DEG, Crowther PR (1990) Paleobiology: a synthesis. Blackwell Scientific, Boston, MA

Butman CA, Carlton JT, Palumbi SR (1995) Whaling effects on deep-sea biodiversity. Conserv Biol 9:462-464

Dean RL, Connell JH (1987) Marine invertebrates in an algal succession. I. Variations in abundance and diversity with succession. J Exp Mar Biol Ecol 109:195-215

Dell RK (1987) Mollusca of the family Mytilidae (Bivalvia) associated with organic remains from deep water off New Zealand, with revisions of the genera Adipicola Dautzenberg, 1927 and Idasola Iredale, 1915. Natl Mus N Z Rec 3: $17-36$

Dell RK (1995) New species and records of deep-water Mollusca from off New Zealand. Tuhinga Rec Mus N Z 2:1-26

Distel DL, Baco AR, Chuang E, Morrill W, Cavanaugh CM, Smith CR (2000) Do mussels take wooden steps to deepsea vents? Nature 403:725-726

Gee JM, Warwick RM (1996) A study of global biodiversity patterns in the marine motile fauna of hard substrata. J Mar Biol Assoc UK 76:177-184

Gibbs PE (1987) A new species of Phascolosoma (Sipuncula) associated with a decaying whale's skull trawled at $880 \mathrm{~m}$ depth in the South-west Pacific. N Z J Zool 14:135-137

Gray JS (2000) The measurement of marine species diversity, with an application to the benthic fauna of the Norwegian continental shelf. J Exp Mar Biol Ecol 250:23-49

Hashimoto J, Ohta S, Gamo T, Chiba H and 6 others (2001) First hydrothermal vent communities from the Indian Ocean discovered. Zool Sci 18:717-721

Hayek LC, Buzas MA (1997) Surveying natural populations. Columbia University Press, New York

Hurlbert SM (1971) The non-concept of species diversity: a critique and alternative parameters. Ecology 52:577-586

Jensen A, Frederiksen R (1992) The fauna associated with the bank-forming deepwater coral Lophelia pertusa (Scleractinaria) on the Faroe Shelf. Sarsia 77:53-69

Jumars PA (1974) Dispersion patterns and species diversity of macrobenthos in two bathyal communities. PhD thesis, Scripps Institute of Oceanography, San Diego, CA

Magurran A (1988) Ecological diversity and its measurement. Croon Helm, London

Marshall BA (1987) Osteopeltidae (Mollusca: Gastropoda): a

Editorial responsibility: Otto Kinne (Editor),

Oldendorf/Luhe, Germany new family of limpets associated with whale bone in the deep-sea. J Molluscan Stud 53:121-127

Marshall BA (1994) Deep-sea gastropods from the New Zealand region associated with recent whale bones and an Eocene turtle. Nautilus 108:1-8

McAleece N, Lambshead PJD, Patterson GLJ, Gage JD (1997) BioDiversity Pro. A program for analyzing ecological data. Natural History Museum, London

McLean JH (1992) Cocculiniform limpets living on whale bone in the deep sea off California. J Molluscan Stud 58: 401-414

Mullineaux LS (1987) Organisms living on manganese nodules and crusts: distribution and abundance at three North Pacific sites. Deep-Sea Res 34:165-184

Pearson TH, Rosenberg R (1978) Macrobenthic succession in relation to organic enrichment and pollution of the marine environment. Oceanogr Mar Biol Annu Rev 16:229-311

Pettibone MH (1993) Polynoid polychaetes associated with a whale skeleton in the bathyal Santa Catalina Basin. Proc Biol Soc Wash 106:678-688

Schuller D, Smith CR, Kadko D (in press) Aging of whale bones using radioisotopes. Earth Planet Sci Lett

Sibuet M, Olu K (1998) Biogeography, biodiversity, and fluid depencdence of deep-sea cold-seep communities at active and passive margins. Deep-Sea Res 45:517-567

Smith CR, Baco AR (1998) Phylogenetic and functional affinities between whale-fall, seep, and vent chemoautotrophic communities. Cah Biol Mar 39:345-346

Smith CR, Baco AR (2003) Ecology of whale falls at the deepsea floor. Oceanogr Mar Biol Annu Rev 41:311-354

Smith CR, Kukert H, Wheatcroft RA, Jumars PA, Deming JW (1989) Vent fauna on whale remains. Nature 341:27-28

Smith CR, Maybaum HL, Baco AR, Pope RH, Carpenter SD, Yager PL, Macko SA, Deming JW (1998) Sediment community structure around a whale skeleton in the deep northeast Pacific: macrofaunal, microbial, and bioturbation effects. Deep-Sea Res 45:335-364

Snelgrove PVR, Smith CR (2002) A riot of species in an environmental calm: the paradox of the species-rich deep-sea floor. Oceanogr Mar Biol Annu Rev 40:311-342

Tunnicliffe V, McArthur AG, McHugh D (1998) A biogeographical perspective of the deep-sea hydrothermal vent fauna. Adv Mar Biol 34:353-442

Van Dover CL, Trask JL (1999) Diversity at deep-sea hydrothermal vent and intertidal mussel beds. Mar Ecol Prog Ser 195:169-178

Van Dover CL, German CR, Speer KG, Parson LM, Vrijenhoek RC (2002) Evolution and biogeography of deep-sea vent and seep invertebrates. Science 295:1253-1257

Waren A (1989) New and little known Mollusca from Iceland. Sarsia 74:1-28

Waren A (1991) New and little known Mollusca from Iceland and Scandinavia. Sarsia 76:53-124

Waren A (1993) New and little known Mollusca from Iceland and Scandinavia. Part 2. Sarsia 78:159-201

Waren A (1996) New and little known Mollusca from Iceland and Scandinavia. Part 3. Sarsia 81:197-245

Williams AB, Smith CR, Baco AR (2000) New species of Paralomis (Decapoda, Anomura, Lithodidae) from a sunken whale carcass in the San Clemente Basin of southern California. J Crustac Biol 20:282-285

Submitted: May 14, 2002; Accepted: May 21, 2003

Proofs received from author(s): September 8, 2003 